\title{
Interchangeability among therapeutic equivalents of lamotrigine: evaluation of quality of life
}

\author{
Beatriz Maria Pereira Girolineto ${ }^{1, *}$, Veriano Alexandre Junior ${ }^{2}$, Américo Ceiki Sakamoto², \\ Leonardo Régis Leira Pereira ${ }^{1}$
}

\begin{abstract}
Department of Pharmaceutical Sciences, Faculty of Pharmaceutical Sciences of Ribeirão Preto, University of São Paulo ${ }^{1}$, Department of Neuroscience and Behavioral Sciences, Faculty of Medicine of Ribeirao Preto, University of São Paulo ${ }^{2}$
\end{abstract}

\begin{abstract}
Epilepsy is the most common serious neurological disorder worldwide. Approximately $70 \%$ of patients with epilepsy have their seizures controlled by clinical and pharmacological treatment. This research evaluated the possible influence of interchangeability among therapeutic equivalents of LTG on the clinical condition and quality of life of refractory epileptic patients. The study was divided into three periods of 42 days, and an equivalent therapeutic LTG randomly dispensed for each period (two similars - formulations A and B, and the reference product - formulation C). The mean dose of LTG was 5.5 $\mathrm{mg} / \mathrm{kg} /$ day. The presence of side effects tends to have a greater deleterious effect on quality of life of refractory epileptics compared to variations in number of seizures or changes in plasma concentrations. The results showed that independently of the drug prescribed, interchangeability among therapeutic equivalents can negatively impact epilepsy control.
\end{abstract}

Uniterms: Epilepsy/treatment. Lamotrigine/therapeutic equivalents. Drugs/interchangeability.

Epilepsia é o distúrbio neurológico grave mais comum no mundo todo. Aproximadamente $70 \%$ dos pacientes com epilepsia têm suas crises controladas com tratamento clínico e farmacológico. Esta pesquisa avaliou a possível interferência da intercambialidade entre equivalentes terapêuticos da lamotrigina na condição clínica e na qualidade de vida dos pacientes com epilepsia refratária. O estudo foi dividido em três períodos de 42 dias e em cada período foi dispensado um equivalente terapêutico, aleatoriamente (dois similares - formulação A e B e o medicamento de referência - formulação C). A dose média de lamotrigina foi de $5,5 \mathrm{mg} / \mathrm{kg} / \mathrm{dia}$. A ocorrência de efeitos colaterais tende a ser mais decisiva para a redução da qualidade de vida em epilepsia refratária em relação às variações no número de crises ou alterações nas concentrações plasmáticas. Os resultados demonstram que, independentemente do medicamento prescrito, a intercambialidade entre equivalentes terapêuticos pode interferir no sucesso do controle da epilepsia.

Unitermos: Epilepsia/tratamento. Epilepsia/controle. Lamotrigina/equivalentes terapêuticos. Medicamentos/intercambialidade.

\section{INTRODUCTION}

Epilepsy is characterized by recurrent and unprovoked seizures constituting a transient sign and symptom of abnormal excessive electrical activity in the cerebral cortex (Fisher et al., 2005). The condition is the most common serious neurological illness worldwide, affecting around 50 million people, 40 million of whom reside

\footnotetext{
*Correspondence: B. M. P. Girolineto. Departamento de Ciências Farmacêuticas, Faculdade de Ciências Farmacêuticas de Ribeirão Preto. Av. do Café, s/ $\mathrm{n}^{\mathrm{o}}$ - Campus Universitário - 14040-903 - Ribeirão Preto - SP, Brasil. E-mail: beatrizgirolineto@gmail.com
}

in developing countries (Burneo, Tellez-Zenteno, Wiebe, 2005; Pellock, 2007). The incidence of epilepsy ranges from 11 to $131 / 100000$ inhabitants per year with a global prevalence of 1.5 to $30 / 1000$ inhabitants. The prevalence of epilepsy in Brazil is between 5.4/1000 and 18.6/1000 (Marino Junior, Cukiert, Pinho, 1986; Borges et al., 2005; Li et al., 2007).

Although recent decades have seen advances in vagal stimulation and surgery for epilepsy (Betting et al., 2003), pharmacological treatment remains the first choice for controlling epilepsy (Löscher, 2002). Improved comprehension of epilepsy in the late twentieth century 
led to the development of new antiepileptic drugs (AEDs) (Brodie, 2003), such as lamotrigine (LTG). However, $30 \%$ of epileptic patients do not respond satisfactorily to pharmacological treatment and are considered refractory.

LTG was approved by the Food and Drug Administration in 1995. For this study, LTG was available in Brazil as Lamictal ${ }^{\circledR}$ (GlaxoSmithKline), considered the reference drug, Lamotrigine (Arrow), the generic drug and as Lamitor ${ }^{\circledR}$ (Torrent Brazil), Lamotrix ${ }^{\circledR}$ (Biolab Sanus), Neural ${ }^{\circledR}$ (Cristália) and Nortrigin ${ }^{\circledR}$ (Meizler), all considered similar drugs. However, to be deemed interchangeable pharmaceutical products need to be both pharmaceutically equivalent and bioequivalent (WHO, 2006), whereas similar drugs in Brazil do not have to be tested for bioequivalence.

The Brazilian National Health System supplies epileptic patients with LTG free of charge, but the prescription of the drug is based on a Clinical Protocol created in 2002 by the State Health Department (Brasil, 2002). The acquisition of LTG by Brazilian public health authorities is based in Federal Law 866 (07/21/1993), which allows acquisition by public tender, where the government invites rival bids for supply of pharmaceutical equivalents (Marin et al., 2003).

During the acquisition of LTG, the public health authorities do not distinguish among reference, generic or similar drugs. Therefore, manufacturers of similar drugs often win the public tender, because they generally practice lower prices in the market. In addition, some public tenders may occur during the year and this increases the possibility of switches in the therapeutic equivalent of the LTG.

The substitution among therapeutic equivalents has been discussed in the literature, because such shifts typically lead to observed changes in clinical efficacy and increases in medical appointments, hospitalizations and side effects (Krämer et al., 2007). This is particularly relevant among refractory epileptic patients, where the risk of recurrence of seizures can cause psychological and social damage, reducing quality of life (Makus, McCormick, 2007).

Besides control of seizures and side effects, quality of life should also be considered during chronic treatment of refractory epilepsy, because this parameter is increasingly important for management of the illness (Seidl, Zannon, 2004), allied with the development of instruments for measuring quality of life in epileptic patients (Wiebe et al., 2002). It is important to highlight that, in different cities throughout Brazil, a lack of adequate knowledge about the disease was noted rendering it a stigmatizing condition influencing patients' activities of daily living and quality of life (Fernandes, Noronha, Sander, 2008; Vancini et al., 2010).

Therefore, the present study evaluated the possible impact on quality of life of refractory epileptic patients of interchangeability among therapeutic equivalents of LTG.

\section{METHODS}

The study was conducted at the Epilepsy Outpatient Clinic of the Ribeirão Preto Medical School University Hospital. The study was prospective and double blind, and previously approved by the Local Research Ethics Committee. Patients were included after meeting the following criteria: refractory epilepsy, at least three seizures in the last six months, age 18 to 65 years, in use of LTG in mono or polytherapy for at least two years, hematological and biochemical tests (renal and hepatic function) without clinically significant changes and agreement to the conditions of the study.

The dosage of LTG and other AEDs used concomitantly were maintained for all patients during the study period and the use of drugs and substances that could interfere with the pharmacokinetics of LTG was not allowed, otherwise the patients were excluded from the study.

The study was divided into three periods of 42 days, spanning a total period of 126 days. For each period, an LTG therapeutic equivalent was randomly dispensed to patients, such that by the end of the study all patients had received two similar drugs (formulation $\mathrm{A}$ and $\mathrm{B}$ ) and a reference drug (formulation C) of LTG; the drugs dispensed were drawn from the same lot. No generic formulation was included in this study, because generic formulation are usually not acquired by the Brazilian public health authorities since they tend to be more expensive than similar drugs.

The first 14 days of each of the three periods were not considered for the final results of number of seizures, plasma concentrations of LTG and side effects, because this interval was needed for reaching the steady state concentration in plasma, ensuring the results were not affected by the therapeutic equivalent of LTG tested previously. The blood collected was used to quantify the plasma concentration of LTG and for biochemical and hematological routine laboratory tests.

\section{Study Procedures}

The treatment was started and patients monitored through clinical appointments held on the following days: zero (baseline), at days 14, 42, 56, 84, 98 and 126 . At baseline, 42 and 84 days all patients received the formulations of the LTG. The diary for recording seizures was 
delivered at baseline and drugs selected were dispensed, with a sufficient number of tablets to last up until the next appointment.

The "Quality of Life in Epilepsy-31 Inventory" (QOLIE-31) is a specific instrument used to measure the quality of life of patients with Epilepsy and was assessed at baseline, and on days 42, 84 and 126. The QOLIE-31 contains 31 questions investigating worry of these patients about their crisis, adverse effects, and cognitive aspects. The instrument is organized into seven domains, namely: Seizure Worry, Emotional Well-Being, Energy/Fatigue, Social Functioning, Cognitive Functioning, Medication Effects, Overall Quality of Life and an additional item assessing overall health status. Each domain is scored from 0 to 100 and the QOLIE-31 also has an overall score of 0 to 100 (Silva et al., 2007).

On days 14, 42, 56, 84, 98 and 126, blood samples were collected for determination of plasma concentrations of LTG. At study end-point, patients returned to the routine of outpatient attendance. The determination of plasma concentrations of LTG was performed using HPLC-UV equipment and the reference interval was $2.5-15.0 \mathrm{mg} / \mathrm{L}$.

The patients were monitored regarding adherence to treatment using the Morisky-Green test, whose score ranges from 0 to 4 , with the latter value indicating the highest degree of adherence to pharmacological treatment.

The results found in this research were split into two parts (clinical data and quality of life) to aid discussion, since the purpose of this paper was to establish a relationship between the interchangeability among therapeutic equivalents of LTG and quality of life of refractory epileptic patients.

\section{Statistical analysis}

The results were assessed using mean \pm standard deviation of the plasma concentration of LTG, number of seizures/week and domains of the QOLIE-31 on Student's $t$-test for independent data. Student's $t$ test and ANOVA were performed by using software Instat ${ }^{\circledR}$ Graph, considering $\mathrm{p}$ values $<0.05$ statistically significant.

\section{RESULTS AND DISCUSSION}

Thirty patients attending the epilepsy center in treatment for refractory epilepsy were invited to participate in the study, where only 13 accepted the invitation. Three subjects were excluded because they started smoking, had a new diagnosis of pseudo-crisis or required adjustment of the dose of other drugs to control seizures. Besides the three previously mentioned exclusions, an individual patient decided to leave the study after the first day. Thus, nine patients completed the study, maintaining the same dose of LTG throughout the 126 days of the study. This condition was necessary to allow comparison among the three formulations.

Seizures were recorded only in the 28 last days of each period for formulations $\mathrm{A}, \mathrm{B}$ and $\mathrm{C}$, disregarding the initial 14 days. Differences in plasma concentrations and number of seizures were not statistically significant for the small number of patients due to the difficulty recruiting according to the protocol. The adherence of patients to pharmacological treatment with LTG was assessed by the Morisky-Green test, and average score obtained was 3.7, 4.0 and 3.7 for the formulations A, B and C, respectively. Thus, the values also showed no significant difference among the three formulations.

Patient 7 presented with a skin rash while using formulation $\mathrm{C}$ and physicians provided early prescription of the another formulation of LTG before the 42 day period. In addition, patients 1, 6 and 9 showed mild side effects (drowsiness, dizziness and memory problems) while using formulation $\mathrm{C}$, however due to the severity and duration of the side effects, the treatment with the formulation $\mathrm{C}$ was not discontinued by the physician. Also, two patients showed an increase in the number of seizures during the use of formulation B, needing to be switched over to another formulation of LTG in this study.

Formulation A of LTG showed better results in the quality of life of epileptic patients than formulations B and C (Tables I, II, and III). Moreover, formulation A of LTG promoted significant improvement in the domains sociability and emotional aspects of the QOLIE-31, this result being due to a small number of seizures and no occurrence of side effects.

Formulation B (Table II) promoted improvement in the global quality of life of patients and in a great number of domains, except vitality, but none of these results was significant. Formulation C (Table III) led to a decrease in the global quality of life of patients, but showed an increase in the domain sociability, albeit without statistical difference. Table IV shows the mean of each formulation across the seven domains of the QOLIE-31.

Interchangeability among therapeutic equivalents during pharmacological treatment in epileptic patients has resulted in several publications, where authors describe that during the interchangeability of therapeutic equivalents, the safety, efficacy and quality of the AEDs may suffer variations. This difference may be relevant in epilepsy, because a small variation can decrease seizure control or promote side effects due to the narrow therapeutic range of most AEDs (Krämer et al., 2007). 
TABLE I - Results (initial versus final) on the QOLIE-31 (total and domains) for formulation A

\begin{tabular}{|c|c|c|c|c|c|c|c|c|c|c|c|c|c|c|c|c|}
\hline \multirow[t]{2}{*}{ Patient } & \multicolumn{2}{|c|}{$\begin{array}{c}\text { Overall } \\
\text { score }\end{array}$} & \multicolumn{2}{|c|}{$\begin{array}{c}\text { Social } \\
\text { functioning }\end{array}$} & \multicolumn{2}{|c|}{$\begin{array}{c}\text { Medication } \\
\text { effects }\end{array}$} & \multicolumn{2}{|c|}{$\begin{array}{l}\text { Cognitive } \\
\text { functioning }\end{array}$} & \multicolumn{2}{|c|}{$\begin{array}{l}\text { Energy- } \\
\text { fatigue }\end{array}$} & \multicolumn{2}{|c|}{$\begin{array}{l}\text { Emotional } \\
\text { well-being }\end{array}$} & \multicolumn{2}{|c|}{$\begin{array}{l}\text { Seizure } \\
\text { worry }\end{array}$} & \multicolumn{2}{|c|}{$\begin{array}{c}\text { Overall } \\
\text { QOL }\end{array}$} \\
\hline & Initial & Final** & Initial & Final* & Initial & Final $^{\text {ns }}$ & Initial & Final $^{\text {ns }}$ & Initial & Final $^{\text {ns }}$ & Initial & Final* & Initial & Final $^{\text {ns }}$ & Initial & Final $^{\text {ns }}$ \\
\hline 1 & 48.36 & 58.12 & 55 & 85 & 33.33 & 50.00 & 63.05 & 58.88 & 50 & 70 & 60 & 72 & 13 & 23 & 77.50 & 82.50 \\
\hline 2 & 44.12 & 47.99 & 35 & 50 & 83.33 & 66.67 & 50.83 & 51.12 & 60 & 65 & 56 & 56 & 60 & 45 & 55.00 & 67.50 \\
\hline 3 & 36.93 & 51.91 & 5 & 22 & 8.33 & 100 & 93.33 & 83.33 & 20 & 70 & 32 & 76 & 20 & 35 & 42.50 & 67.50 \\
\hline 4 & 62.38 & 66.63 & 65 & 60 & 100 & 100 & 73.62 & 76.95 & 60 & 85 & 60 & 80 & 95 & 100 & 72.50 & 77.50 \\
\hline 5 & 76.48 & 80.95 & 80 & 100 & 100 & 100 & 100 & 100 & 100 & 100 & 60 & 80 & 96 & 100 & 65.00 & 62.50 \\
\hline 6 & 48.88 & 69.54 & 46 & 65 & 100 & 100 & 47.22 & 86.67 & 90 & 100 & 64 & 96 & 47 & 65 & 42.50 & 77.50 \\
\hline 7 & - & 69.23 & - & 70 & - & 100 & - & 67.22 & - & 95 & - & 100 & - & 81 & - & 100 \\
\hline 8 & 69.87 & 50.31 & 80 & 65 & 100 & 91.67 & 80.28 & 52.78 & 85 & 50 & 96 & 56 & 100 & 64 & 62.50 & 55.00 \\
\hline 9 & 38.37 & 50.47 & 47 & 75 & 16.67 & 50.00 & 30.00 & 48.88 & 70 & 75 & 64 & 72 & 18 & 28 & 65.00 & 55.00 \\
\hline$\overline{\text { Mean }}$ & 53 & 58 & 52 & 66 & 68 & 84 & 67 & 70 & 67 & 79 & 62 & 76 & 56 & 60 & 60 & 72 \\
\hline
\end{tabular}

Legend: * statistically significant difference $(\mathrm{p}<0.05)$; ** statistically significant difference $(\mathrm{p}<0.01)$; ) ns: no statistically significant difference $(\mathrm{p}>0.05)$.

TABLE II - Results (initial versus final) on QOLIE-31 (total and domains) for formulation B

\begin{tabular}{|c|c|c|c|c|c|c|c|c|c|c|c|c|c|c|c|c|}
\hline \multirow[t]{2}{*}{ Patient } & \multicolumn{2}{|c|}{ Overall score } & \multicolumn{2}{|c|}{$\begin{array}{c}\text { Social } \\
\text { functioning }\end{array}$} & \multicolumn{2}{|c|}{$\begin{array}{c}\text { Medication } \\
\text { effects }\end{array}$} & \multicolumn{2}{|c|}{$\begin{array}{l}\text { Cognitive } \\
\text { functioning }\end{array}$} & \multicolumn{2}{|c|}{$\begin{array}{l}\text { Energy- } \\
\text { fatigue }\end{array}$} & \multicolumn{2}{|c|}{$\begin{array}{l}\text { Emotional } \\
\text { well-being }\end{array}$} & \multicolumn{2}{|c|}{$\begin{array}{l}\text { Seizure } \\
\text { worry }\end{array}$} & \multicolumn{2}{|c|}{$\begin{array}{c}\text { Overall } \\
\text { QOL }\end{array}$} \\
\hline & Initial & Final $^{\text {ns }}$ & Initial & Final $^{\text {ns }}$ & Initial & Final $^{\text {ns }}$ & Initial & Final $^{\text {ns }}$ & Initial & Final $^{\mathrm{ns}}$ & Initial & Final $^{\text {ns }}$ & Initial & Final $^{\text {ns }}$ & Initial & Final $^{\text {ns }}$ \\
\hline 2 & 47.99 & 44.38 & 50 & 55 & 66.67 & 83.33 & 51.12 & 50.55 & 65 & 55 & 56 & 56 & 45 & 28 & 67.50 & 50.00 \\
\hline 3 & 51.91 & 57.62 & 22 & 45 & 100 & 75.00 & 83.33 & 96.67 & 70 & 60 & 76 & 72 & 35 & 13 & 67.50 & 75.00 \\
\hline 6 & 65.27 & 66.97 & 53 & 80 & 83.33 & 100 & 93.33 & 63.62 & 80 & 95 & 76 & 76 & 100 & 100 & 55.00 & 67.50 \\
\hline 7 & 63.04 & 80.68 & 100 & 80 & 83.33 & 100 & 59.72 & 96.67 & 80 & 100 & 48 & 100 & 15 & 91 & 85.00 & 100 \\
\hline 8 & 43.54 & 63.05 & 55 & 75 & 83.33 & 91.67 & 30.83 & 57.78 & 75 & 90 & 72 & 80 & 51 & 85 & 50.00 & 72.50 \\
\hline 9 & 50.47 & 49.19 & 75 & 67 & 50.00 & 33.33 & 48.88 & 54.17 & 75 & 55 & 72 & 60 & 28 & 23 & 55.00 & 72.50 \\
\hline$\overline{\text { Mean }}$ & 55 & 62 & 65 & 66 & 69 & 83 & 69 & 75 & 76 & 74 & 68 & 76 & 55 & 64 & 64 & 70 \\
\hline
\end{tabular}

Legend: ns: no statistically significant difference ( $\mathrm{p}>0.05)$.

TABLE III - Results (initial versus final) on QOLIE-31 (total and domains) for formulation C

\begin{tabular}{|c|c|c|c|c|c|c|c|c|c|c|c|c|c|c|c|c|}
\hline \multirow[t]{2}{*}{ Patient } & \multicolumn{2}{|c|}{ Overall score } & \multicolumn{2}{|c|}{$\begin{array}{c}\text { Social } \\
\text { functioning }\end{array}$} & \multicolumn{2}{|c|}{$\begin{array}{c}\text { Medication } \\
\text { effects }\end{array}$} & \multicolumn{2}{|c|}{$\begin{array}{l}\text { Cognitive } \\
\text { functioning }\end{array}$} & \multicolumn{2}{|c|}{$\begin{array}{l}\text { Energy- } \\
\text { fatigue }\end{array}$} & \multicolumn{2}{|c|}{$\begin{array}{l}\text { Emotional } \\
\text { well-being }\end{array}$} & \multicolumn{2}{|c|}{$\begin{array}{c}\text { Seizure } \\
\text { worry }\end{array}$} & \multicolumn{2}{|c|}{$\begin{array}{c}\text { Overall } \\
\text { QOL }\end{array}$} \\
\hline & Init & Final $^{\text {ns }}$ & Init & Final $^{\text {ns }}$ & Init & Final $^{\text {ns }}$ & Init & Final $^{\text {ns }}$ & Init & Final $^{\text {ns }}$ & Init & Final $^{\text {ns }}$ & Init & Final $^{\text {ns }}$ & Init & Fin $^{\text {ns }}$ \\
\hline 1 & - & 52.93 & - & 50 & - & 41.67 & - & 69.72 & - & 70 & - & 68 & - & 48 & - & 65.00 \\
\hline 2 & 44.38 & 45.89 & 55 & 50 & 83.33 & 75.00 & 50.55 & 53.62 & 55 & 60 & 56 & 52 & 28 & 46 & 50.00 & 50.00 \\
\hline 3 & 57.62 & 76.19 & 45 & 95 & 75.00 & 75.00 & 96.67 & 93.33 & 60 & 90 & 72 & 84 & 13 & 56 & 75.00 & 87.50 \\
\hline 4 & 61.44 & 62.38 & 55 & 65 & 83.33 & 100 & 82.78 & 73.62 & 60 & 60 & 76 & 60 & 95 & 95 & 65.00 & 72.50 \\
\hline 5 & 68.92 & 77.40 & 68 & 100 & 100 & 100 & 100 & 100 & 75 & 85 & 88 & 80 & 74 & 100 & 60.00 & 50.00 \\
\hline 6 & 66.97 & 46.88 & 80 & 46 & 100 & 100 & 63.62 & 47.22 & 95 & 90 & 76 & 64 & 100 & 47 & 67.50 & 42.50 \\
\hline 7 & 80.68 & - & 80 & - & 100 & - & 96.67 & - & 100 & - & 100 & - & 91 & - & 100 & - \\
\hline 8 & 63.05 & 69.87 & 75 & 80 & 91.67 & 100 & 57.78 & 80.28 & 90 & 85 & 80 & 96 & 85 & 100 & 72.50 & 62.50 \\
\hline 9 & 49.19 & 37.19 & 67 & 51 & 33.33 & 25.00 & 54.17 & 37.50 & 55 & 5 & 60 & 60 & 23 & 5 & 72.50 & 50.00 \\
\hline Mean & 62 & 59 & 66 & 67 & 83 & 77 & 72 & 69 & 74 & 68 & 76 & 71 & 64 & 62 & 70 & 61 \\
\hline
\end{tabular}

Legend: ns: no statistically significant difference $(\mathrm{p}>0.05)$. 
TABLE IV - Mean scores on QOLIE-31 (total and domains)

\begin{tabular}{lcccc}
\hline Therapeutic Equivalent & Initial & $\mathrm{F} \mathrm{A}^{\mathrm{ns}}$ & $\mathrm{F} \mathrm{B}^{\mathrm{ns}}$ & $\mathrm{F} \mathrm{C}^{\mathrm{ns}}$ \\
\hline Overall score & $\mathbf{5 6 . 1 9 0}( \pm \mathbf{1 9 . 5 3 5})$ & $\mathbf{6 0 . 5 7 2}( \pm \mathbf{1 1 . 4 7 9})$ & $\mathbf{6 1 . 5 3 1}( \pm \mathbf{1 1 . 4 3 3})$ & $\mathbf{5 8 . 4 6 6}( \pm \mathbf{1 4 . 9 8 5})$ \\
Social functioning & $53.111( \pm 26.540)$ & $65.778( \pm 21.919)$ & $65.625( \pm 12.872)$ & $67.125( \pm 21.781)$ \\
Medication Effects & $54.628( \pm 39.332)$ & $83.333( \pm 22.204)$ & $83.291( \pm 22.397)$ & $77.125( \pm 14.985)$ \\
Cognitive functioning & $68.543( \pm 28.042)$ & $69.540( \pm 18.042)$ & $75.278( \pm 20.984)$ & $69.409( \pm 22.054)$ \\
Energy-Fatigue & $66.667( \pm 22.500)$ & $78.889( \pm 17.280)$ & $73.750( \pm 18.851)$ & $74.375( \pm 14.745)$ \\
Emotional well-being & $58.222( \pm 12.979)$ & $76.444( \pm 15.158)$ & $76.000( \pm 14.182)$ & $70.500( \pm 14.803)$ \\
Seizure worry & $52.556( \pm 38.204)$ & $58.333( \pm 31.977)$ & $63.625( \pm 36.063)$ & $62.125( \pm 33.677)$ \\
Overall QOL & $60.556( \pm 13.851)$ & $71.667( \pm 14.416)$ & $70.313( \pm 14.481)$ & $60.625( \pm 14.01)$ \\
\hline
\end{tabular}

Legend: ns: no statistically significant difference $(\mathrm{p}>0.05)$.

The Brazilian Agency of Sanitary Vigilance (ANVISA) allows and regulates the commercialization of reference, generic and similar drugs by Resolution RDC 17 (03/03/2007). The similar drugs must contain the same active moiety, concentration, form, route of administration, dosage and therapeutic indication, and must be equivalent to the product registered at the ANVISA. However, the similar drugs may differ in the characteristics related to size and shape of the product, besides packaging and excipients.

Law 9787/99 provides for the creation of generic drugs and Resolution 391 (09/08/1999) of the ANVISA allows the interchangeability among generic and reference drugs. This same law stipulates that similar drugs must be approved on a bioequivalence test, but these similar drugs are marketed without passing the bioequivalence test because the regulatory legislation that requires this has been approved, but does not yet take effect. However, during the public tender process, the Brazilian health authorities allow the participation of reference, generic and similar drugs with the latter usually winning the public tender because of their lower price.

In addition, during the year some public tenders are executed by Brazilian health authorities and this fact supports interchangeability among therapeutic equivalents of the LTG. However, this change during the pharmacological treatment often occurs in parallel to modifications in size or color of the drug and/or packaging, which can reduce compliance, because generally the patients have doubts whether this "new drug" is the same drug as that received before. This problem is most common in patients with cognitive problems, often found among epileptics. Moreover, this change frequently raises anxiety, increasing reports of side effects (Krämer et al., 2007).

A study has shown, according to clinical experience of the neurologists involved, that $68 \%$ of cases of interchangeability among reference and generic AEDs result in recurrence of seizures in previously-controlled patients (Wilner, 2004). The substitution of Lamictal ${ }^{\circledR}$ for a generic drug in epileptic patients, evaluated by 71 pharmacists and 130 physicians, showed an increase in seizures (Makus, McCormick, 2007). Another study observed that the interchangeability did not reduce cost, because it generally results in an increase and/or addition of another drug to treatment and also increases medical utilization (Labiner et al., 2010).

Thus, the prescription of generic, similar or reference drug has been suggested only at the beginning of the epilepsy pharmacological treatment, where the physician is charged with choosing the most appropriate pharmaceutical equivalent (Krämer et al., 2007; Bialer, 2007). For patients who are free of seizures and side effects, interchangeability among AEDs is not recommended (Bialer, 2007).

In the United States of America, 95\% of epileptics agree that the interchangeability among therapeutic equivalent of AEDs promote increased seizures and/or side effects (Macauley et al., 2009), where it is commonplace for patients to return to the formulation used previously (Andermann et al., 2007).

Table V shows that the interchangeability among therapeutic equivalents of LTG did not promote significant alterations in mean plasma concentrations of LTG or in number of seizures, where only patient 6 showed no change in seizures during the study. Moreover, higher mean plasma concentrations of LTG were found for formulation B compared to other formulations, where this coincided with an increase in seizures/week. These results on the impact of interchangeability among therapeutics equivalents on plasma concentration of LTG and on the number of seizures/week (clinical data) were discussed in another study by the researchers (Girolineto et al., 2010).

Seizure control is important in refractory epilepsy, but increasing the dose of AEDs to achieve this goal, usu- 
TABLE V - Gender, age, dose, plasma concentration and seizure/week for formulations A, B and C of lamotrigine

\begin{tabular}{|c|c|c|c|c|c|c|c|c|c|c|c|c|}
\hline \multirow{3}{*}{ Patient } & \multirow{3}{*}{ Gender } & \multirow{3}{*}{ Age } & \multirow{3}{*}{$\begin{array}{c}\text { Dose (mg/ } \\
\mathrm{kg} / \text { day) }\end{array}$} & \multicolumn{6}{|c|}{${\text { [plasma }]_{\mathrm{LTG}}}$} & \multicolumn{3}{|c|}{ seizure / week } \\
\hline & & & & \multicolumn{2}{|c|}{$\mathrm{FA}^{\mathrm{ns}}$} & \multicolumn{2}{|c|}{$\mathrm{FB}^{\text {ns }}$} & \multicolumn{2}{|c|}{$\mathrm{F} \mathrm{C}^{\mathrm{ns}}$} & \multirow[b]{2}{*}{$\mathrm{FA}^{\mathrm{ns}}$} & \multirow[b]{2}{*}{$\mathrm{FB}^{\mathrm{ns}}$} & \multirow[b]{2}{*}{$\mathrm{F} \mathrm{C}^{\mathrm{ns}}$} \\
\hline & & & & $14^{\text {th }}$ day & $42^{\text {nd }} d a y^{\text {ns }}$ & $14^{\text {th }}$ day & $42^{\text {nd }} d a y^{\text {ns }}$ & $14^{\text {th }}$ day & $42^{\text {nd }} d a y^{\text {ns }}$ & & & \\
\hline 1 & $\bar{F}$ & 19 & 6.51 & 4.60 & 6.70 & 8.00 & - & 4.70 & 5.53 & 0.75 & - & 0.50 \\
\hline 2 & M & 51 & 7.16 & 2.40 & 1.80 & 1.77 & 3.00 & 1.50 & 2.40 & 2.50 & 4.25 & 5.25 \\
\hline 3 & $\mathrm{~F}$ & 22 & 6.24 & 6.62 & 13.92 & 7.80 & 5.55 & 5.10 & - & 0.50 & 7.89 & 0 \\
\hline 4 & $\mathrm{~F}$ & 56 & 5.99 & 2.40 & 3.00 & 3.70 & 3.02 & 2.30 & 3.38 & 1.00 & 4.50 & 3.25 \\
\hline 5 & $\mathrm{~F}$ & 56 & 3.15 & 3.36 & 2.16 & - & - & 3.70 & 6.20 & 0 & 4.00 & 0.25 \\
\hline 6 & F & 58 & 5.62 & 1.64 & - & 2.70 & 3.80 & 12.90 & 2.20 & 0 & 0 & 0 \\
\hline 7 & M & 28 & 5.00 & 10.90 & 9.80 & 12.60 & 16.90 & 5.70 & - & 1.50 & 0.25 & - \\
\hline 8 & M & 31 & 6.46 & 4.10 & 1.74 & - & 2.40 & 1.60 & 3.80 & 0.75 & 0.25 & 0.75 \\
\hline 9 & M & 43 & 3.52 & 4.85 & 4.60 & - & 8.50 & 5.00 & 4.30 & 0.25 & 1.50 & 1.50 \\
\hline Mean & & $\begin{array}{c}40.44 \\
( \pm 15.63) \\
\end{array}$ & $\begin{array}{c}5.52 \\
( \pm 1.38)\end{array}$ & $\begin{array}{c}4.54 \\
( \pm 2.83) \\
\end{array}$ & $\begin{array}{c}5.47 \\
( \pm 4.42)\end{array}$ & $\begin{array}{c}6.10 \\
( \pm 4.12)\end{array}$ & $\begin{array}{c}6.17 \\
( \pm 5.18)\end{array}$ & $\begin{array}{c}4.72 \\
( \pm 3.45)\end{array}$ & $\begin{array}{c}3.97 \\
( \pm 1.50)\end{array}$ & $\begin{array}{c}0.81 \\
( \pm 0.80)\end{array}$ & $\begin{array}{c}2.83 \\
( \pm 2.80) \\
\end{array}$ & $\begin{array}{c}1.44 \\
( \pm 1.88)\end{array}$ \\
\hline
\end{tabular}

Legend: ns: no statistically significant difference $(\mathrm{p}>0.05)$; F: formulation

ally results in reduced of quality of life due to side effects (Perucca, 2000). Therefore, this study evaluated the impact of interchangeability among therapeutic equivalents of LTG on quality of life of refractory epilepsy patients based on the QOLIE-31. Refractory epilepsy severely impacts quality of life of patients due to the psychosocial disorders caused by the recurrence of seizures and the stigma and discrimination that increases during the evolution of the illness (Perucca, 2000).

Formulation A of LTG led to higher scores on the QOLIE-31 across the seven domains (Table I), while formulation B showed increase in six domains (Table II). The reduction observed in vitality caused by formulation $\mathrm{B}$, although not significant, may be related to the increase in mean plasma concentration of LTG which can promote the occurrence of side effects (nausea, headache, depression, irritability and skin rash) (Mackay et al., 1997). Formulation C of LTG showed improvement only on the sociability domain of the QOLIE-31, reducing the final score of quality of life, but the alterations were not considered statistically significant (Table III).

These results demonstrate that formulation A received the best rating with regard to quality of life, probably because this therapeutic equivalent showed better control over seizures and no side effects during the study. Table IV shows that the results obtained for the formulations A, B and C on the QOLIE-31 all showed improvement compared to baseline values.

However, evaluating the results for formulations B and $\mathrm{C}$, reveals that the presence of side effects tends to carry greater weight in terms of the quality of life rating of refractory epileptic patients than number of seizures, be- cause although formulation $\mathrm{C}$ reduced number of seizures compared to formulation $\mathrm{B}$, the results showed that due to its side effects (although mild and transient), formulation $\mathrm{C}$ was associated with lower scores on the QOLIE-31.

Generally, epileptic teenagers have more social and cultural problems compared to epileptic adults, and this tends to more greatly reduce the quality of life these patients (Ding et al., 2008). Elsharkawy et al. (2009) demonstrated that the duration of seizures and presence of side effects caused by AEDs have a greater negative impact on quality of life during the pharmacological treatment of epilepsy. The same authors observed that psychosocial factors, such employment, social independence and psychiatric complications also adversely affect quality of life (Elsharkawy et al., 2009).

Phabphal et al. (2009) found that the frequency of seizures, depression and anxiety were responsible for decreases in quality of life of refractory epileptic patients. However, other factors evaluated (age, gender, occupation, marital status and medications) did not influence the results on the QOLIE-31. Piperidou et al. (2008) evaluated 223 patients with mean age of 35.2 years and 13 years of epilepsy, and found that reduced quality of life was related to high seizure frequency and polytherapy, especially when patients used benzodiazepines associated with AEDs. Another study in Turkey also demonstrated that epileptic patients in polytherapy had lower quality of life compared to monotherapy patients (Giray et al., 2009).

One limitation of this study is the number of subjects $(n=9)$ included, involving a small sample precluding generalizations.

The authors can conclude that interchangeability 
hampers control of refractory epilepsy due to the likelihood of increasing seizures, presence of side effects and changes in plasma concentrations of LTG. Consequently, it proves difficult to maintain high scores on the QOLIE-31 and reduction in quality of life can result.

Despite these results and the problem of similar drugs, the authors emphasize that the free supply of LTG is laudable, because it facilitates access of low income patients to high-cost drugs and allows physician greater choice for pharmacological treatment. Nevertheless, Brazilian health authorities should review the situation of similar drugs and find mechanisms to avoid frequent replacement of the therapeutic equivalent during treatment, because results show that independent of reference, generic or similar drugs, interchangeability among therapeutic equivalents tends to increase the likelihood of failure in the pharmacological treatment of refractory epilepsy.

\section{REFERENCES}

ANDERMANN, F.; DUH, M.S.; GOSSELIN, A.; PARADIS, P.E. Compulsory generic switching of antiepileptic drugs: high switchback rates to branded compounds compared with other drug classes. Epilepsia, v.48, n.3, p.464-469, 2007.

BETTING, L.E.; KOBAYASHI, E.; MONTENEGRO, M.A.; MIN, L.L.; CENDES, F.; GUERREIRO, M.M.; GUERREIRO, C.A.M. Tratamento de epilepsia: consenso dos especialistas brasileiros. Arq. Neuro-Psiquiat., v.61, n.4, p.1045-1070, 2003.

BIALER, M. Generic products of antiepileptics drugs (AEDs): Is it an issue? Epilepsia, v.48, n.10, p.1825-1832, 2007.

BORGES, M.A.; MIN, L.L.; GUERREIRO, C.A.M.; YACUBIAN, E.M.T.; CORDEIRO, J.A.; TOGNOLA, W.A.; BORGES, A.P.P.; ZANETTA, D.M.T. Urban prevalence of epilepsy: populational study in São José do Rio Preto, a medium-sized city in Brazil. Arq. NeuroPsiquiat., v.62, n.2a, p.199-205, 2004.

BRASIL. Secretaria de Atenção à Saúde. Portaria n ${ }^{\circ} 864$, de 05 de novembro de 2002. Protocolo clínico e diretrizes terapêuticas para epilepsia refratária. Lex: coletânea de legislação e jurisprudência. Brasília, 2002. p.293-301.

BRODIE, M.J. Building new understandings in epilepsy: maximizing patient outcomes without sacrificing seizure control. Epilepsia, v.44, n.S4, p.1-2, 2003.
BURNEO, J.G; TELLEZ-ZENTENO, J.; WIEBE, S. Understanding the burden of epilepsy in Latin America: a systematic review of its prevalence and incidence. Epilepsy Res., v.66, n.1-3, p.63-74, 2005.

DING, D.; HONG, Z.; CHEN, G.S.; DAI, X.Y.; WU, J.Z.; WANG, W.Z.; DE BOER, H.M.; SANDER, J.W.; PRILIPKO, L.; CHISHOLM, D. Primary care treatment of epilepsy with phenobarbital in rural China: cost-outcome analysis from the WHO/ILAE/IBE global campaign against epilepsy demonstration project. Epilepsia, v.49, n.3, p.535539, 2008.

ELSHARKAWY, A.E.; MAY, T.; THORBECKE, R.; KOCH-STOECKER, S.; VILLAGRAN, A.; URAK, L.; PFÄFFLIN, M.; PANNEK, H.; PIETILÄ, T.A.; EBNER, A. Long-term outcome and determinants of quality of life after temporal lobe epilepsy surgery in adults. Epilepsy Res., v.86, n.2-3, p.191-199, 2009.

FERNANDES, P.T.; NORONHA, A.L.A.; SANDER, J.W.; LI, L.M. Stigma scale of epilepsy: the perception of epilepsy stigma in different cities in Brazil. Arq. Neuro-Psiquiat., v.66, n.3, p.471-476, 2008.

FISHER, R.S.; VAN EMDE BOAS, W.; BLUME, W.; ELGER, C.; GENTON, P.; LEE, P.; ENGEL JR, J. Epileptic seizures and epilepsy: definitions proposed by the International League Against Epilepsy (ILAE) and the International Bureau for Epilepsy (IBE). Epilepsia, v.46, n.4, p.470-472 2005.

GIRAY, S.; OZENLI, Y.; OZISIK, H.; KARACA, S.; ASLANER, U. Health-related quality of life of patients with epilepsy in Turkey. J. Clin. Neurosci., v.16, n.12, p.1582-1587, 2009.

GIROLINETO, B.M.P.; ALEXANDRE JR, V.; QUEIROZ, R.H.C.; FELETTI, F.; SAKAMOTO, A.C.; PEREIRA, L.R.L. Intercambiabilidad entre equivalentes terapéuticos de lamotrigina en pacientes con epilepsia refractaria: riesgos y beneficios. Rev. Neurologia, v.51, n.6, p.330-336, 2010.

KRÄMER, G.; BIRABEN, A.; CARRENO, M.; GUEKHT, A.; DE HAAN, G.J.; JEDRZEJCZAK, J.; JOSEPHS, D.; VAN RIJCKEVORSEL, K.; ZACCARA, G. Current approaches to the use of generic antiepileptic drugs. Epilepsy Behav., v.11, n.1, p.46-52, 2007. 
MACAULEY, J.W.; CHEN, A.Y.; ELLIOTT, J.O.; SHNEKER, B.F. An assessment of patient and pharmacist knowledge of and attitudes toward reporting adverse drug events due to formulation switching in patients with epilepsy. Epilepsy Behav., v.14, n.1, p.113-117, 2009.

MACKAY, F.J.; WILTON, L.V.; PEACE, G.L.; FREEMANTLE, S.N.; MANN, R.D. Safety of long-term lamotrigine in epilepsy. Epilepsia, v.38, n.8, p.881-886, 1997.

MAKUS, K.G.; MCCORMICK, J. Identification of adverse reactions that can occur on substitution of generic for branded lamotrigine in patients with epilepsy. Clin. Ther., v.29, n.2, p.334-341, 2007.

MARIN, N.; LUIZA, V.L.; OSORIO DE CASTRO, C.G.S.; MACHADO DOS SANTOS, S. Assistência Farmacêutica para agentes municipais. 20.ed. Rio de Janeiro: OPAS, 2003. $175 \mathrm{p}$.

MARINO JR, R.; CUKIERT, A.; PINHO, E. Aspectos epidemiológicos da epilepsia em Säo Paulo: um estudo da prevalência. Arq. Neuro-Psiquiat., v.44, n.3, p.243-254, 1986.

LABINER, D.M.; PARADIS, P.E.; MANJUNATH, R.; DUH, M.S.; LAFEUILLE, M.H.; LATRÉMOUILLE-VIAU, D.; LEFEBVRE, P.; HELMERS, S.L. Generic antiepileptic drugs and associated medical resource utilization in the United States. Neurology, v.74, n.20, p.1566-1574, 2010.

LI, L.M.; FERNANDES, P.T.; NORONHA, A.L.A.; MARQUES, L.H.N.; BORGES, M.A.; CENDES, F.; GUERREIRO, C.A.M.; ZANETTA, D.M.T.; DE BÔER, H.M.; ESPÍNDOLA, J.; MIRANDA, C.T.; PRILIPKO, L.; SANDER, J.W. Demonstration project on epilepsy in Brazil: situation assessment. Arq. Neuro-Psiquiat., v.65, suppl.1, p.5-13, 2007.

LÖSCHER, W. Current status and future directions in the pharmacotherapy of epilepsy. Trends Pharmacol. Sci., v.23, n.3, p.113-118, 2002.

PELLOCK, J.M. Overview: Definitions and classifications of seizure emergencies. J. Child Neurol., v.22, n.5, p.9s-13s, 2007.

PERUCCA, E. Is there a role for therapeutic drug monitoring of new anticonvulsants? Clin. Pharmacokinet., v.38, n.3, p.191-204, 2000.
PHABPHAL, K.; GEATER, A.; LIMAPICHART, K.; SATIRAPUNYA, P.; SETTHAWATCHARAWANICH, S. Quality of life in epileptic patients in southern Thailand. $J$. Med. Assoc. Thai., v.92, n.6, p.762-768, 2009.

PIPERIDOU, C.; KARLOVASITOU, A.; TRIANTAFYLLOU, N.; DIMITRAKOUDI, E.; TERZOUDI, A.; MAVRAKI, E.; TRYPSIANIS, G.; VADIKOLIAS, K.; HELIOPOULOS, I.; VASSILOPOULOS, D.; BALOGIANNIS, S. Association of demographic, clinical and treatment variables with quality of life of patients with epilepsy in Greece. Qual. life res., v.17, n.7, p.987-996, 2008.

SEIDL, E.M.F.; ZANNON, C.M.L.C. Qualidade de vida e saúde: aspectos conceituais e metodológicos. Cad. Saúde Pública, v.20, n.2, p.580-588, 2004.

SILVA, T.I.; CICONELLI, R.M.; ALONSO, N.B.; AZEVEDO, A.M.; WESTPHAL-GUITTI, A.C.; PASCALICCHIO, T.F.; MARQUES, C.M.; CABOCLO, L.O.S.F.; CRAMER, J.A.; SAKAMOTO, A.C.; YACUBIAN, E.M.T. Validity and reliability of the portuguese version of the quality of life in epilepsy inventory (QOLIE-31) for Brazil. Epilepsy Behav., v.10, n.2, p.234-241, 2007.

VANCINI, R.L.; LIRA, C.A.; GOMES DA SILVA, S.; SCORZA, F.A.; SILVA, A.C.; VIEIRA, D.; CAVALHEIRO, E.A.; ARIDA, R.M. Evaluation of physical educators' knowledge about epilepsy. Arq. Neuro-Psiquiat., v.68, n.3, p.367-371, 2010.

WIEBE, S.; MATIJEVIC, S.; ELIASZIW, M.; DERRY, P.A. Clinically important change in quality of life in epilepsy. $J$. Neurol. Neurosur. Ps., v.73, n.2, p.116-120, 2002.

WILNER, A.N. Therapeutic equivalency of generic antiepileptic drugs: results of a survey. Epilepsy Behav., v.5, n.6, p.995998, 2004.

WORLD HEALTH ORGANIZATION. The WHO Technical Report Series Multisource (generic) pharmaceutical products: Guidelines on registration requirements to establish interchangeability. In: WHO Expert Committee on Specifications for Pharmaceutical Preparations. WHO Technical Report Series, n.937, p.347-390, 2006. Available at: $<$ http://www.who.int/medicines/publications/ BrochurePharmaupdatedversion.pdf $>$. Accessed on: 11 out. 2011.

Received for publication on $24^{\text {th }}$ April 2011 Accepted for publication on $13^{\text {th }}$ December 2011 